\title{
Ice walking common frog (Rana temporaria) (Ranidae, Amphibia)
}

\author{
K. D. Milto \\ Zoological Institute, Russian Academy of Sciences \\ 1 Universitetskaya Emb., Saint Petersburg 199034, Russia
}

\author{
Article info \\ Short Communication \\ https://doi.org/10.18500/1814-6090- \\ 2021-21-1-2-52-54 \\ Received 14 January 2021, \\ revised 22 January 2021 , \\ accepted 27 January 2021 \\ This article is an open access article \\ distributed under the terms and condi-tions \\ of the Creative Commons Attribution 4.0 \\ License
}

\begin{abstract}
A record of Rana temporaria on the ice cover of the Gulf of Finland is described. Frog slowly moved on the ice surface with speed around $0.03 \mathrm{~m} / \mathrm{s}$. Air temperature near ice surface was $+3.5^{\circ} \mathrm{C}$, and the frog body temperature was $+4^{\circ} \mathrm{C}$. In the Saint Petersburg region, common frogs can hibernate in the coastal waters of Baltic Sea with salinity of $0-5.8 \%$.

Keywords: Common frog, Rana temporaria, ice cover crossing, hibernation, Saint Petersburg,
\end{abstract} Gulf of Finland

Acknowledgments: The study was carried out in the framework of the State Theme of the Zoological Institute, Russian Academy of Sciences (No. AAAA-A19-119020590095-9).

For citation: Milto K. D. Ice walking common frog (Rana temporaria) (Ranidae, Amphibia). Current Studies in Herpetology, 2021, vol. 21, iss. 1-2, pp. 52-54. https://doi.org/10.18500/ 1814-6090-2021-21-1-2-52-54
Rana temporaria has the most northerly distribution of any amphibians in the Europe and occurs beyond the Arctic Circle in Scandinavia (Grossenbacher, 1997; Kuzmin, 2013). Really, these frogs do not have resistance to complete body freezing and rather quickly die at stable ambient temperatures below $0^{\circ} \mathrm{C}$. Rana temporaria belongs to amphibian species wintering in the water bodies, which is the reason for the lack of adaptations to subzero temperatures (Pasanen, Karhapaa, 1997; Kutenkov, 2009; Berman, Bulakhova, 2019). Despite this, frogs sometimes can found on the ice surface. Thus, in the French Alps more than 6000 feet high, common frogs breed in the partly frozen pond and forced to cross the ice cover to reach the open water (White, 2011).

Throughout its range, Rana temporaria usually overwinters in streams, rivers, or the coastal part of lakes, preferably with a rocky bottom. In the Saint Petersburg region these frogs also can hibernate in coastal waters of the Gulf of Finland and Neva Bay. After hibernation, Rana temporaria are the first among other amphibian species leaves their overwintering quarters, while large reservoirs are still covered with ice. In St. Petersburg the breeding process usually started in the middle of April, an ice cover can remain on large bodies of water until early May.

On 21 April 2013, at 14:32 h, active male of Rana temporaria was recorded on the ice cover (Fig. 1) in the coastal zone of Gulf of Finland near Kotlin Island (60.028559, 29.647789), Kronstadt District, Saint Petersburg, Russia. The frog slowly moved (Fig. 2) on the ice surface from the nearby ice opening towards the coast, which was $50 \mathrm{~m}$ from the opening. Frog speed was around $0.03 \mathrm{~m} / \mathrm{s}$. Air temperature near ice surface was $3.5^{\circ} \mathrm{C}$, and frog body temperature was $4^{\circ} \mathrm{C}$. Leaving the ice-opening, the frog was forced to overcome the ice space separating him from the Kotlin Island coast. The coastal shallow part was completely covered by the ice cover to the bottom and prevented movement under the ice.

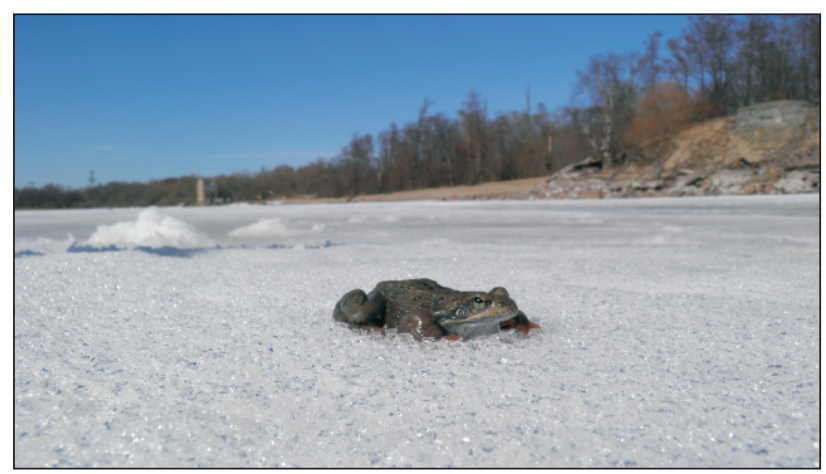

Fig 1. Rana temporaria on the ice cover near Kotlin Island, Saint Petersburg, Russia, 21 April 2013

\footnotetext{
Corresponding author. Laboratory of Herpetology of Zoological Institute, Russian Academy of Sciences, Russia.

ORCID and e-mail addresse: Konstantin D. Milto: coluber@zin.ru
}

(C) Milto K. D., 2021 


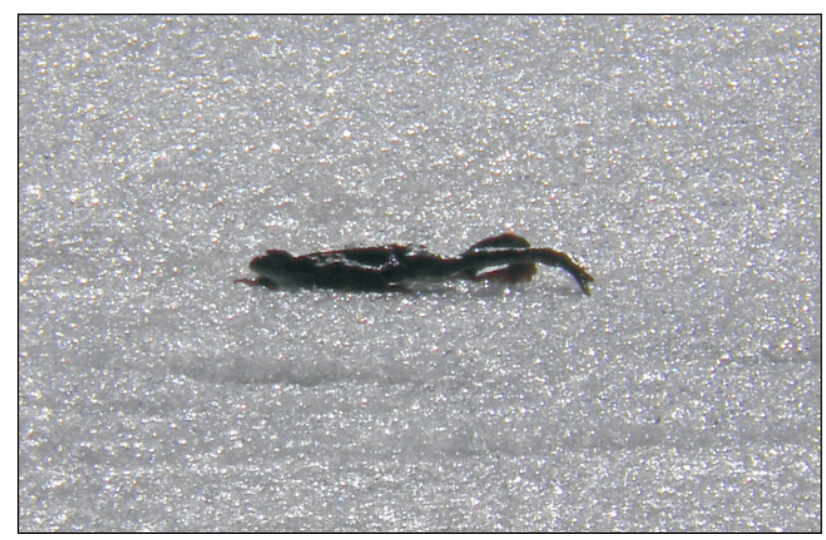

Fig. 2. Rana temporaria walking on the ice near Kotlin Island, Saint Petersburg, Russia, 21 April 2013

The Kotlin Island is located in the eastern part of the Gulf of Finland, at the entrance to the Neva Bay. Natural vegetation represented on the western part of island by alder and aspen forests. The small waterbodies like ponds and flooded willow brushwoods are common and used by amphibians as breeding sites. At the same time, there are no flowing water bodies suitable for underwater wintering frogs. Of the four amphibian species inhabiting the island, two species (Lissotriton vulgaris, Rana arvalis) hibernate on the land. Another two (Rana temporaria, Pelophylax ridibundus) wintering underwater and are forced to hiber- nate in the waters of the Gulf of Finland. Neva Bay belongs to freshwater bodies with the salinity of $0.1 \%$, eastern part of Gulf of Finland is brackish water body with the salinity of $0-5.8 \%$. It is known that Rana temporaria and Pelophylax ridibundus not only hibernate, but also breed in the Neva Bay and the Gulf of Finland (Milto, 2008).

\section{REFERENCES}

Berman D. I., Bulakhova N. A. How winterkill suffocations stop the common frog spreading from Europe to Asia. Priroda, 2019, no. 7, pp. 12-26 (in Russian). https://doi.org/10.7868/S0032874X19070020

Grossenbacher K. Rana temporaria Linnaeus, 1758. In: J.-P.Gasc, ed. Atlas of Amphibians and Reptiles in Europe. Paris, Museum national d'Histoire naturelle, 1997, pp. 158-159.

Kutenkov A. P. Ecology of the Common Frog in the North-Western Russia. Petrozavodsk, Petrozavodsk State University Publ., 2009. 140 p. (in Russian).

Kuzmin S. L. The Amphibians of the Former Soviet Union. Sofia, Moscow, Pensoft Publ., 2013, 384 p.

Milto K. D. Amphibians breed in the Baltic sea. Russian Journal Herpetology, 2008, vol. 15, no. 1, pp. 8-10. https://doi.org/10.30906/1026-2296-2008-15-1-8-10

Pasanen S., Karhapaa M. Can boreal common frog (Rana temporaria L.) survive in frost $^{\circ}$ Annales Zoologici Fennici, 1997, vol. 34, pp. 247-250.

White M. Indomitable snow frogs. National Geographic, 2011, vol. 219, no. 4, pp. 138-145. 


\title{
K. D. Milto
}

\section{Травяная лягушка (Rana temporaria) (Ranidae, Amphibia) на поверхности льда}

\author{
К. Д. Мильто
}

Зоологический институт РАН

Россия, 199034, г. Санкт-Петербург, Университетская набережная, д. 1

\section{Информация о статье \\ Краткое сообщение \\ УДК 597.851(470.23-25) \\ https://doi.org/10.18500/1814-6090-2021-21- \\ $1-2-52-54$}

Поступила в редакцию 14.01.2021, после доработки 22.01.2021, принята 27.01.2021

Статья опубликована на условиях лицензии Creative Commons Attribution License (CC-BY 4.0)
Аннотация. Описывается встреча травяной лягушки (Rana temporaria) на поверхности льда Финского залива. Лягушка медленно перемещалась от полыньи к берегу со скоростью $0.03 \mathrm{M} / \mathrm{c}$. Температура воздуха у поверхности льда составляла $+3.5^{\circ} \mathrm{C}$, а температура тела лягушки была $+4^{\circ} \mathrm{C}$. В окрестностях Санкт-Петербурга травяные лягушки могут зимовать в прибрежных водах Балтийского моря, солёность которых колеблется в пределах $0-5.8 \%$.

Ключевые слова: травяная лягушка, Rana temporaria, перемещение по льду, зимовка, Санкт-Петербург, Финский залив

Финансирование: Исследование выполнено в рамках гостемы Зоологического института РАН (№ AAAAA19-119020590095-9).

Образец для цитирования: Milto K. D. Ice walking common frog (Rana temporaria) (Ranidae, Amphibia) [Мильто К. Д. 2021. Травяная лягушка (Rana temporaria) (Ranidae, Amphibia) на поверхности льда] // Современная герпетология. Т. 21, вып. 1/2. С. 52 - 54. https://doi.org/10.18500/1814-6090-2021-21-1-2-52-54

\footnotetext{
Для корреспонденции. Лаборатория герпетологии Зоологического института РАН.

ORCID и e-mail aдpec: Мильто Константин Дмитриевич: coluber@zin.ru.
} 